\section{New York's biotech beginnings}

\section{By C. Simone Fishburn, Senior Editor}

New York has long produced top science but has struggled to retain and develop its own innovations. The city says it hopes a flurry of public-private partnerships, real estate developments and high-profile academic appointments will help establish it as a biotech hub. But VCs say New York will have to produce or attract experienced management in order to persuade them to seed local companies.

Unlike the translational hubs in the San Francisco Bay Area and Boston that sprouted spontaneously, the interest in New York is the result of city policies to grow the biotech industry in the region.

Maria Gotsch, president and CEO of the Partnership Fund for New York City, told SciBX that the desire to promote biotech dates to the early 2000s, as leaders of several city institutions noticed a mismatch between the amount and quality of life sciences research and the number of companies being created.
"In the early days, a VC would fly in, go along First Avenue, stand outside Rockefeller and bring three things: a CEO, a bag of cash and a moving van to take it somewhere else."

- Maria Gotsch,

Partnership Fund for New York City
"There was a disconnect between the academic science quality and the amount of land space," she said.

In 2003, she noted that Boston and New York received similar amounts of NIH funding-about $\$ 1.5$ billion and $\$ 1.3$ billion, respectively. At the time, she said, Boston had more than 12 million square feet in commercial lab space, whereas New York had only about 120,000 .

That obstacle has largely been addressed, Gotsch said, with the opening in the last four years of the Alexandria Center for Life Science, the Harlem Biospace incubator and the BioBAT at the Brooklyn Army Terminal.

The Alexandria Center is a 15-story commercial facility with laboratory and office space located on 3.5 acres of city-owned land in Manhattan between Bellevue Hospital and New York University.

Eli Lilly and Co. signed up as the anchor tenant in 2010, and Roche inaugurated its Translational and Clinical Research Center (TCRC) in the Alexandria Center in October 2013.

Judith Dunn, global head of clinical development at Roche's Pharma Research and Early Development (pRED) unit, said that the company chose to set up in New York because it wanted access to external innovation via peer-to-peer interactions with teaching hospitals and medical schools.

The TCRC houses about 200 employees working on all aspects of development from drug discovery to regulatory science, and it serves as the U.S. operations base for the company's North American clinical trials.

Dunn said that in addition to the concentration and proximity of high-quality

Gotsch noted that New York City contains nine of the country's top medical centers, and the state ranks in the top three for NIH awards. However, until recently, the majority of biotech innovations from many top New York institutions were used to launch companies in other cities.

"Keeping commercialization of biomedical sciences in New York is a problem we've been working on for the last decade," Gotsch told SciBX. "In the early days, a VC would fly in, go along First Avenue, stand outside Rockefeller and bring three things: a CEO, a bag of cash and a moving van to take it somewhere else."

There were myriad reasons that academic innovations ended up elsewhere, including insufficient lab space, a dearth of commercial interest and a lack of biotech-focused venture firms.

In the last four years, New York has addressed the first two issues by finding space and money for new labs and creating several significant early stage partnerships between academia and industry. By recruiting academic leaders with industry experience and launching commercially focused translational programs, the city hopes to attract venture funding and create a biotech ecosystem.

\section{Landing biotech}

According to Gotsch, one of the key challenges to starting companies in New York was the limited availability of affordable real estate for building wet labs. science, New York's multicultural population is a big advantage for the pharma's clinical operations. "In translational medicine you want bench scientists close to physicians. You also want a diverse population so that you can think about genomics in a macro way-New York is almost uniquely suited to this," she told SciBX.

In addition, she said, the fact that New York has attracted top talent with industry experience to lead some of its academic and medical centers was a significant draw.

Those high-profile appointments include Marc Tessier-Lavigne as president of The Rockefeller University, Louis Walcer as head of Cornell University's life science business incubator and Laurie Glimcher as dean of Weill Cornell Medical College, all in 2011.

Tessier-Lavigne was previously EVP and CSO at the Genentech Inc. unit of Roche; Walcer was senior commercialization officer at Cleveland Clinic Innovations, the technology commercialization arm of the Cleveland Clinic; and Glimcher was a professor at Harvard Medical School and a practicing rheumatologist at Brigham and Women's Hospital.

Pfizer Inc. also has leased space at the Alexandria Center for its Center for Therapeutic Innovation. Joel Marcus said that more than a dozen other life science companies have leased space, including smalland medium-sized biotechs. 
Table 1. Boosting translation in New York academia. Select public-private partnerships (PPPs) and charitable donations involving New York Citybased organizations since January 2013. The table includes only partnerships for translational programs in therapeutic areas or technologies and excludes partnerships to develop specific company products.

Source: BioCentury archives

\begin{tabular}{|c|c|c|c|c|c|}
\hline Date & Companies or donors & Institutions & $\begin{array}{l}\text { Disease/ } \\
\text { indication/ } \\
\text { tool }\end{array}$ & Description & $\begin{array}{l}\text { Funding } \\
\text { amount }\end{array}$ \\
\hline \multicolumn{6}{|c|}{ PPPs and donations with disclosed funding } \\
\hline $\begin{array}{l}\text { September } \\
2013\end{array}$ & Genia Technologies Inc. & $\begin{array}{l}\text { Columbia University; Harvard } \\
\text { University; NIH }\end{array}$ & Genomics & $\begin{array}{l}\text { Three-year grant from NIH's National } \\
\text { Human Genome Research Institute } \\
\text { to develop Genia's NanoTag sequencing } \\
\text { technology, which combines technologies } \\
\text { from the three institutes }\end{array}$ & $\$ 5.3$ million \\
\hline $\begin{array}{l}\text { October } \\
2013\end{array}$ & $\begin{array}{l}\text { Takeda Pharmaceutical Co. } \\
\text { Ltd. (Tokyo:4502); Lewis } \\
\text { and Ali Sanders; Howard } \\
\text { and Abby Milstein }\end{array}$ & $\begin{array}{l}\text { Memorial Sloan-Kettering Cancer } \\
\text { Center (MSKCC); The Rockefeller } \\
\text { University; Weill Cornell Medical } \\
\text { College }\end{array}$ & Multiple & $\begin{array}{l}\text { Tri-Institutional Therapeutics Discovery } \\
\text { Institute Inc. launched to expedite early } \\
\text { stage discovery into clinical treatments and } \\
\text { therapies }\end{array}$ & $\begin{array}{l}\$ 20 \text { million }+ \\
\$ 1.5 \text { million/ } \\
\text { year }\end{array}$ \\
\hline $\begin{array}{l}\text { December } \\
2013\end{array}$ & $\begin{array}{l}\text { Celgene Corp. } \\
\text { (NASDAQ:CELG); Eli } \\
\text { Lilly and Co. (NYSE:LLY); } \\
\text { General Electric Co. } \\
\text { (NYSE:GE) }\end{array}$ & $\begin{array}{l}\text { New York City Economic } \\
\text { Development Corp. }\end{array}$ & Multiple & $\begin{array}{l}\text { City of New York Early-Stage Life } \\
\text { Sciences Funding Initiative to invest } \\
\text { at least } \$ 100 \text { million in early stage life } \\
\text { science companies in the city }\end{array}$ & $\$ 100$ million \\
\hline $\begin{array}{l}\text { January } \\
2014\end{array}$ & $\begin{array}{l}\text { Virginia and D.K. Ludwig } \\
\text { Fund for Cancer Research }\end{array}$ & $\begin{array}{l}\text { MSKCC; The Johns Hopkins } \\
\text { University; Harvard University; } \\
\text { Massachusetts Institute of } \\
\text { Technology; Stanford University; } \\
\text { The University of Chicago }\end{array}$ & Cancer & $\begin{array}{l}\text { Funding for cancer research at six } \\
\text { universities }\end{array}$ & $\begin{array}{l}\text { \$540 million } \\
\text { (including } \\
\$ 90 \text { million } \\
\text { for MSKCC) }\end{array}$ \\
\hline $\begin{array}{l}\text { March } \\
2014\end{array}$ & $\begin{array}{l}\text { NIH's National Institute } \\
\text { of Allergy and Infectious } \\
\text { Diseases }\end{array}$ & $\begin{array}{l}\text { Rockefeller University; Fred } \\
\text { Hutchinson Cancer Research Center; } \\
\text { NIH; Seattle Biomedical Research } \\
\text { Institute; Seattle Children's Hospital; } \\
\text { University of Washington }\end{array}$ & Infectious disease & $\begin{array}{l}\text { Consortium to develop a vaccine to elicit } \\
\text { broadly neutralizing antibodies against } \\
\text { HIV-1 }\end{array}$ & $\$ 9.8$ million \\
\hline $\begin{array}{l}\text { March } \\
2014\end{array}$ & $\begin{array}{l}\text { Emergent BioSolutions } \\
\text { Inc. (NYSE:EBS); Mapp } \\
\text { Biopharmaceutical Inc.; } \\
\text { Zalgen Labs LLC }\end{array}$ & $\begin{array}{l}\text { Yeshiva University; Ben-Gurion } \\
\text { University of the Negev; NIH; } \\
\text { Public Health Agency of Canada; } \\
\text { The Scripps Research Institute; } \\
\text { Uganda Virus Research Institute; } \\
\text { The University of Texas Medical } \\
\text { Branch; University of Wisconsin } \\
\text { System; U.S. Army Medical Research } \\
\text { Institute of Infectious Diseases }\end{array}$ & Infectious disease & $\begin{array}{l}\text { Consortium to develop immunotherapies } \\
\text { for filoviruses and arenaviruses that cause } \\
\text { severe hemorrhagic fever }\end{array}$ & $\begin{array}{l}\text { Up to } \$ 28 \\
\text { million }\end{array}$ \\
\hline April 2014 & $\begin{array}{l}\text { UCB Group } \\
\text { (Euronext:UCB) }\end{array}$ & Weill Cornell Medical College & Multiple & $\begin{array}{l}\text { Advance translational research programs in } \\
\text { bone disorders, metabolic disease and rare } \\
\text { genetic variant analysis. UCB receives right } \\
\text { to negotiate an exclusive license to develop } \\
\text { and commercialize resulting products }\end{array}$ & $\$ 8$ million \\
\hline May 2014 & $\begin{array}{l}\text { Marie-Josée and Henry R. } \\
\text { Kravis Foundation }\end{array}$ & MSKCC & Cancer & $\begin{array}{l}\text { Creation of the Marie-Josée and Henry } \\
\text { R. Kravis Center for Molecular Oncology } \\
\text { (CMO) to develop cancer treatments through } \\
\text { genomic analysis of patient-derived tumors }\end{array}$ & $\$ 100$ million \\
\hline \multicolumn{6}{|c|}{ PPPs with undisclosed or unavailable funding details } \\
\hline $\begin{array}{l}\text { February } \\
2013\end{array}$ & Genisphere LLC & Mount Sinai Hospital & $\begin{array}{l}\text { Inflammation; } \\
\text { diagnostics }\end{array}$ & $\begin{array}{l}\text { Partnership to develop a high throughput, } \\
\text { semiautomatic, peptide-based diagnostic } \\
\text { to characterize food allergies }\end{array}$ & $\begin{array}{l}\text { Undisclosed/ } \\
\text { unavailable }\end{array}$ \\
\hline May 2013 & $\begin{array}{l}\text { Foundation Medicine Inc. } \\
\text { (NASDAQ:FMI) }\end{array}$ & MSKCC & Diagnostics & $\begin{array}{l}\text { Partnership to co-develop a molecular } \\
\text { diagnostic product to match patients } \\
\text { with hematologic cancers with targeted } \\
\text { therapies or clinical trials based on } \\
\text { patients' genomic profiles }\end{array}$ & $\begin{array}{l}\text { Undisclosed/ } \\
\text { unavailable }\end{array}$ \\
\hline July 2013 & $\begin{array}{l}\text { Johnson \& Johnson } \\
\text { (NYSE:JNJ) }\end{array}$ & $\begin{array}{l}\text { Icahn School of Medicine at Mount } \\
\text { Sinai }\end{array}$ & $\begin{array}{l}\text { Inflammatory } \\
\text { bowel disease } \\
\text { (IBD) }\end{array}$ & $\begin{array}{l}\text { Partnership to investigate triggers of IBD, } \\
\text { identify new opportunities for therapeutic } \\
\text { interventions and create diagnostics for } \\
\text { therapeutics, and identify predictive } \\
\text { biomarkers }\end{array}$ & $\begin{array}{l}\text { Undisclosed/ } \\
\text { unavailable }\end{array}$ \\
\hline
\end{tabular}


Table 1. Boosting translation in New York academia. (continued)

\begin{tabular}{|c|c|c|c|c|c|}
\hline Date & Companies or donors & Institutions & $\begin{array}{l}\text { Disease/ } \\
\text { indication/ } \\
\text { tool }\end{array}$ & Description & $\begin{array}{l}\text { Funding } \\
\text { amount }\end{array}$ \\
\hline $\begin{array}{l}\text { September } \\
2013\end{array}$ & Exosome Diagnostics Inc. & $\begin{array}{l}\text { Icahn School of Medicine at Mount } \\
\text { Sinai }\end{array}$ & Diagnostics & $\begin{array}{l}\text { Partnership to develop real-time, nucleic } \\
\text { acid-based body fluid diagnostics for } \\
\text { research and biomarker discovery } \\
\text { programs in oncology, inflammation and } \\
\text { other disease areas }\end{array}$ & $\begin{array}{l}\text { Undisclosed/ } \\
\text { unavailable }\end{array}$ \\
\hline $\begin{array}{l}\text { October } \\
2013\end{array}$ & Berg Pharma LLC & $\begin{array}{l}\text { Icahn School of Medicine at Mount } \\
\text { Sinai }\end{array}$ & Multiple & $\begin{array}{l}\text { Partnership to discover and develop } \\
\text { biologics, small molecules and diagnostic } \\
\text { tools for cancer and CNS and endocrine } \\
\text { disorders }\end{array}$ & $\begin{array}{l}\text { Undisclosed/ } \\
\text { unavailable }\end{array}$ \\
\hline $\begin{array}{l}\text { October } \\
2013\end{array}$ & BioMotiv LLC & $\begin{array}{l}\text { Alzheimer's Drug Discovery } \\
\text { Foundation; University Hospitals } \\
\text { Case Medical Center }\end{array}$ & $\begin{array}{l}\text { Alzheimer's } \\
\text { disease (AD) }\end{array}$ & $\begin{array}{l}\text { Partnership to advance preclinical AD } \\
\text { therapeutics in U.S. academic medical } \\
\text { institutions }\end{array}$ & $\begin{array}{l}\text { Undisclosed/ } \\
\text { unavailable }\end{array}$ \\
\hline $\begin{array}{l}\text { January } \\
2014\end{array}$ & Sutro Biopharma Inc. & MSKCC & Cancer & $\begin{array}{l}\text { Partnership to produce bispecific } \\
\text { antibodies developed by Sutro against } \\
\text { targets discovered by MSKCC for } \\
\text { treatment of neuroblastoma in children }\end{array}$ & $\begin{array}{l}\text { Undisclosed/ } \\
\text { unavailable }\end{array}$ \\
\hline $\begin{array}{l}\text { March } \\
2014\end{array}$ & IBM (NYSE:IBM) & New York Genome Center & Pharmacogenetics & $\begin{array}{l}\text { Partnership to evaluate a prototype of } \\
\text { IBM's Watson cognitive system as a } \\
\text { genomic research tool to help oncologists } \\
\text { deliver personalized care initially for } \\
\text { patients with glioblastoma }\end{array}$ & $\begin{array}{l}\text { Undisclosed/ } \\
\text { unavailable }\end{array}$ \\
\hline
\end{tabular}

Marcus is chairman, CEO and founder of Alexandria Real Estate Equities Inc.

The Harlem Biospace incubator is the brainchild of Columbia University professor Sam Sia, who cofounded it to provide academic entrepreneurs with low-cost lab space that is close to the university. The incubator has leased space to about 20 startups since it opened last November.

Sia is an associate professor of biomedical engineering at Columbia and cofounder of Claros Diagnostics Inc., which was acquired by Opko Health Inc. for $\$ 49$ million in 2011.

The Brooklyn BioBAT is a 500,000-squarefoot facility founded by the New York City Economic Development Corp. (NYCEDC) together with SUNY Downstate Medical Center, with laboratory space currently available for lease.

\section{Funding translation}

The availability of commercial space has

\section{"In translational medicine you want bench scientists close to physicians. You also want a diverse population so that you can think about genomics in a macro way- New York is almost uniquely suited to this."}

-Judith Dunn, Roche
Cornell Tech applied sciences campus on Roosevelt Island and is part of the city's wider strategy to reap the benefits of its own intellectual assets.

"We want to ensure that the science that gets discovered here gets developed here," he said.

"What's new is that now we're trying to retain the commercial value of our brains here," added Geoffrey Smith, director of the Mount Sinai Institute of Technology and a professor of health evidence and policy at the Icahn School of Medicine at Mount Sinai. "The commercial strength of our biology has been overlooked because of the strength of the financial services. We're in the conversation now as a place that this is happening."

In addition, New York-based not-forprofit organizations and philanthropic funds are now backing local translational initiatives.

Two of these are directed toward oncology research at Memorial Sloan-Kettering Cancer Center (MSKCC).

In mid-May, MSKCC received $\$ 100$ to translational science. Since the start of 2013, city, commercial and philanthropic funds in New York City have committed more than $\$ 300$ million to public-private partnerships and academic centers for local translational programs (see Table 1, "Boosting translation in New York academia").

In January, NYCEDC announced the largest of these- $-\$ 100$ million for early stage life sciences. The goal of the funding initiative is to spur the creation of 15-20 new companies by 2020 .

NYCEDC, Celgene Corp., Eli Lilly and GE Ventures committed a joint $\$ 50$ million in anchor money and are seeking matching funds from VCs.

Eric Gertler, EVP of the NYCEDC, told SciBX that the initiative came on the heels of $\$ 100$ million committed by the city to help build the million from the Marie-Josée and Henry R. Kravis Foundation to use cancer treatments; in January, MSKCC received $\$ 90$ million from the Virginia and D.K. Ludwig Fund for Cancer Research. In total, the fund gave $\$ 540$ million to 6 institutions.

In October 2013, Lewis and Ali Sanders gave a \$15 million gift and Howard and Abby Milstein gave $\$ 5$ million to help found TriInstitutional Therapeutics Discovery Institute Inc. The institute, which will develop small molecules from early discovery to clinical trials, is a consortium between MSKCC, Rockefeller University, Weill Cornell Medical College and Takeda Pharmaceutical Co. Ltd.

The pharma is contributing $\$ 1.5$ million per year. genomic analysis of patient-derived tumors to advance personalized 

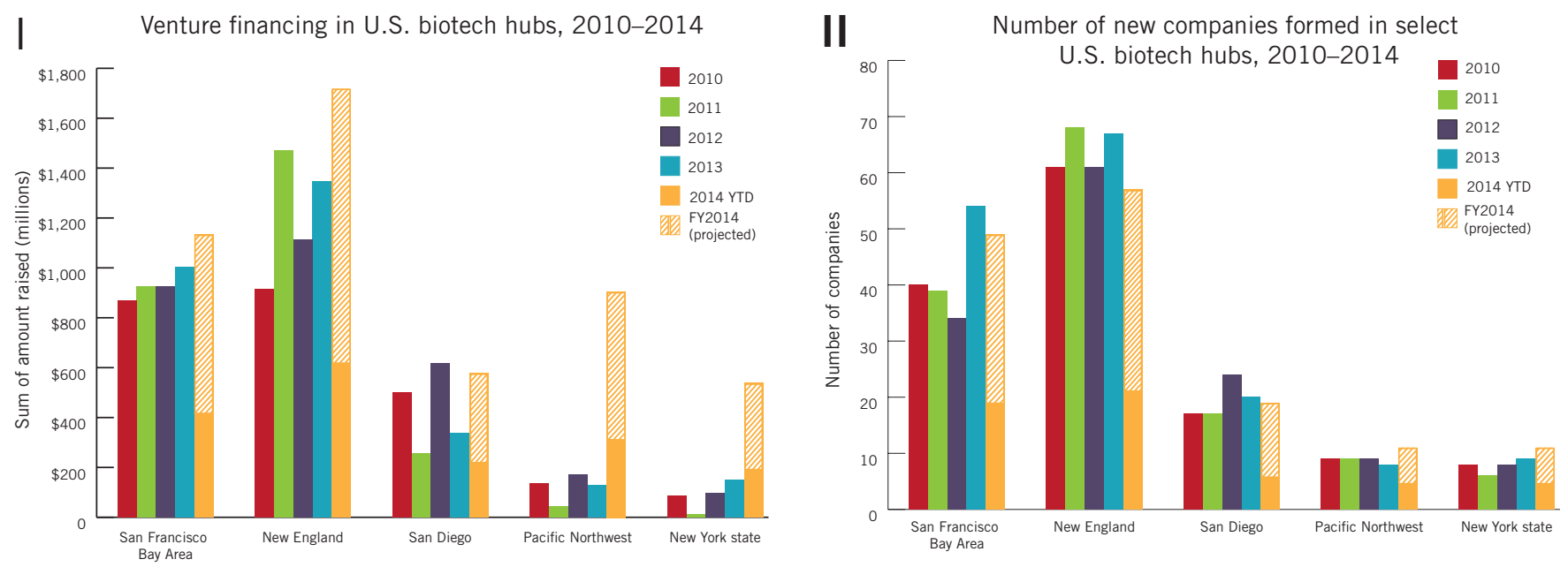

Figure 1. Slow to venture in New York. (I) Venture financing in U.S. biotech hubs, 2010-2014. Sum of amount raised in disclosed venture financing in select U.S. regions. (II) Number of new companies formed in select U.S. biotech hubs, 2010-2014. Data for 2014 is year to date (YTD). Stippled bars show projection for fiscal year 2014 (FY2014) based on YTD amounts. Source: BCIQ: BioCentury Online Intelligence

\section{Capital gap}

Although many parts of the ecosystem are now in place, there is still relatively little biotech VC activity in the region.

According to Gotsch, the next hurdle is to bring in capital for early stage companies. Although there has been some investment in companies with Phase II and later programs, hardly any money has gone into seeding new companies, she told SciBX.

In the last four years, the total amount of venture funding in New York State has trailed even the smaller hubs of San Diego and the Pacific Northwest, and it is far behind the two biggest hubs in the San Francisco Bay Area and Boston-Cambridge. In all five regions, the amount raised to date in 2014 is outpacing prior years.

In addition, the number of new companies founded in New York remains fairly static at under 10 per year (see Figure 1, "Slow to venture in New York").

According to Gotsch, the lack of new company formation deprives the region of the supply of people with industry experience that new ventures need. "When you don't have a track record of companies and exits, you don't have a deep bench of experienced management. The scientist inventor is often not the best CEO," she said.

Atlas Venture's Jean-François Formela agreed and said that it is particularly difficult to establish a cluster in a city with other wellestablished industries that offer attractive alternatives for local talent.

"All the pluses in favor of New York are pretty obvious-academic excellence, clinical strength, translational centers. There's also a lot of money in New York. But the key missing piece is the talent pool and the ability to recruit scientists and build companies in a setting that's conducive to forming a cluster," he said.

"The fact that New York is a cluster for so many other industries is a challenge. It has financial services, advertising, media and so many other industries," he added.
"As a VC here in New York we're at an extreme disadvantage, especially for early stage companies, because we're not in the middle of an ecosystem," said Martin Vogelbaum, partner at Rho Ventures.

He added that New York lacks an area like Cambridge's Kendall Square, where coffee shops and hotels full of biotech executives and entrepreneurs lead to impromptu meetings and provide a good environment for deal making.

According to Polaris Partners' Kevin Bitterman, the limited pool of experienced talent in New York is partly because the region has not had any significant home-grown, large companies to serve as feeders for new startups.

"If you look at companies [in the Bay Area and Boston] that were started and successful in the last few years, the management team will have folks from the big companiesMillennium, Genentech, Genzyme-these are phenomenal training grounds for growing talent," he said.

Development Corp.

Millennium is now part of Takeda, Genentech is part of Roche and Genzyme is owned by Sanofi.

The recruitment of Roche and Eli Lilly to New York, and Pfizer's expansion of its translational research activities there, could help catalyze change.

"When pharma put down its roots in Boston, that really helped trigger the growth in that region," Formela said. He cautioned that a pharma footprint does not replace the need for people with startup experience. "The talent pool that you need for a biotech hub is different from pharma," noted Formela.

Indeed, Scott Friedman, dean for therapeutic discovery and a professor of medicine at the Icahn School of Medicine, said that the academics in the region still have precious little experience with starting companies.

"You need a cultural change for an innovation ecosystem," he said. "You need to have both the appetite and the infrastructure for change." 


\section{ANALYSIS}

\section{TRANSLATIONAL NOTES}

Smith said that they are bringing about that change at Sinai and other institutions by creating programs to teach translational science and having senior faculty directly involved with industry.

Those strategies-together with the city's investment in the sectorare starting to pay off among scientists, he told SciBX.

"Now there is a concerted effort being made in New York to build biotech here by local government and academic centers, and it's happening on the grass roots side too. People have started to believe you can be entrepreneurial."

Fishburn, C.S. SciBX 7(21); doi:10.1038/scibx.2014.603

Published online May 29, 2014

\section{COMPANIES AND INSTITUTIONS MENTIONED}

Alexandria Center for Life Science, New York, N.Y. Alexandria Real Estate Equities Inc., Pasadena, Calif.

Atlas Venture, Cambridge, Mass.

Bellevue Hospital, New York, N.Y.

BioBAT, New York, N.Y.

Brigham and Women's Hospital, Boston, Mass. Celgene Corp. (NASDAQ: CELG), Summit, N.J.

Cleveland Clinic, Cleveland, Ohio

Cleveland Clinic Innovations, Cleveland, Ohio
Columbia University, New York, N.Y.

Cornell Tech, New York, N.Y.

Cornell University, New York, N.Y.

Eli Lilly and Co. (NYSE:LLY), Indianapolis, Ind.

GE Ventures, Menlo Park, Calif.

Genentech Inc., South San Francisco, Calif.

Harlem Biospace, New York, N.Y.

Harvard Medical School, Boston, Mass.

Icahn School of Medicine at Mount Sinai, New York, N.Y.

Memorial Sloan-Kettering Cancer Center, New York, N.Y.

New York City Economic Development Corp., New York, N.Y.

New York University, New York, N.Y.

Opko Health Inc. (NYSE:OPK; Tel Aviv:OPK), Miami, Fla.

Partnership Fund for New York City, New York, N.Y.

Pfizer Inc. (NYSE:PFE), New York, N.Y.

Polaris Partners, Boston, Mass.

Rho Ventures, New York, N.Y.

Roche (SIX:ROG; OTCQX:RHHBY), Basel, Switzerland

The Rockefeller University, New York, N.Y.

Sanofi (Euronext:SAN; NYSE:SNY), Paris, France

SUNY Downstate Medical Center, Brooklyn, N.Y.

Takeda Pharmaceutical Co. Ltd. (Tokyo:4502), Osaka, Japan

Tri-Institutional Therapeutics Discovery Institute Inc., New York, N.Y.

Weill Cornell Medical College, New York, N.Y. 